Article

\title{
Real-Time Ozone Sensor Based on Selective Oxidation of Methylene Blue in Mesoporous Silica Films
}

\author{
Christelle Ghazaly ${ }^{1,2}{ }^{10}$, Marc Hébrant ${ }^{2}$, Eddy Langlois ${ }^{1}$, Blandine Castel ${ }^{1}$, \\ Marianne Guillemot ${ }^{1, *}$ and Mathieu Etienne ${ }^{2, *(\mathbb{D}}$ \\ 1 Département de Métrologie des Polluants, Institut National de Recherche et de Sécurité (INRS), \\ 54500 Vandœuvre-lès-Nancy, France \\ 2 Laboratoire de Chimie Physique et Microbiologie pour les Matériaux et l'Environnement (LCPME), \\ UMR 7564 CNRS-Université de Lorraine, 405 rue de Vandœuvre, 54600 Villers-lès-Nancy, France \\ * Correspondence: marianne.guillemot@inrs.fr (M.G.); mathieu.etienne@univ-lorraine.fr (M.E.)
}

Received: 9 July 2019; Accepted: 8 August 2019; Published: 10 August 2019

\begin{abstract}
Sensitive and selective personal exposure monitors are needed to assess ozone $\left(\mathrm{O}_{3}\right)$ concentrations in the workplace atmosphere in real time for the analysis and prevention of health risks. Here, a cumulative gas sensor using visible spectroscopy for real-time $\mathrm{O}_{3}$ determination is described. The sensing chip is a mesoporous silica thin film deposited on transparent glass and impregnated with methylene blue (MB). The sensor is reproducible, stable for at least 50 days, sensitive to $10 \mathrm{ppb}$ $\mathrm{O}_{3}$ (one-tenth of the occupational exposure limit value in France, Swiss, Canada, U.K., Japan, and the USA) with a measurement range tested up to $500 \mathrm{ppb}$, and insensitive to $\mathrm{NO}_{2}$ and to large variation in relative humidity. A model and its derivative as a function of time are proposed to convert in real time the sensor response to concentrations, and an excellent correlation was obtained between those data and reference $\mathrm{O}_{3}$ concentrations. This sensor is based on a relatively cheap sensing material and a robust detection system, and its analytical performance makes it suitable for monitoring real-time $\mathrm{O}_{3}$ concentrations in workplaces to promote a safer environment for workers.
\end{abstract}

Keywords: ozone; optical gas sensor; mesoporous silica; methylene blue; occupational exposure

\section{Introduction}

Ozone $\left(\mathrm{O}_{3}\right)$ is a powerful oxidizing gas and a strong disinfectant used in different processes, including water treatment, gas purification, textile bleaching, and food industries. In workplaces, $\mathrm{O}_{3}$ is mainly emitted into the atmosphere from the processes of UV radiation and electric arc welding [1]. Another source of exposure in tertiary and service sectors is the extensive use of laser printers and photocopiers [2].

In France, the occupational exposure limits values (OELs) for $\mathrm{O}_{3}$ exposure are $100 \mathrm{ppb}$ and $200 \mathrm{ppb}$ for exposure times of $8 \mathrm{~h}$ and $15 \mathrm{~min}$, respectively [3]. These values are consistent with other European or international OELs (see Table $\mathrm{S} 1$ in Supporting Information). At an $\mathrm{O}_{3}$ concentration exceeding OELs, exposure becomes hazardous to human health, causing headache, burning eyes, lung damage, and respiratory diseases such as asthma [4]. Therefore, it is necessary to monitor $\mathrm{O}_{3}$ concentrations in workplaces, using a personal monitor that provides real-time measurements of $\mathrm{O}_{3}$ exposure levels with high resolution in both time and concentration. Currently, chemical analysis techniques based on individual sampling on solid adsorbents or filters are used to determine concentrations of $\mathrm{O}_{3}$ [5-9], but delayed analysis of the samples in chemical laboratories is required. These techniques do not provide an alert in real time in the case of high exposure. Moreover, the obtained data are only average concentrations over extended periods. 
Recently, numerous $\mathrm{O}_{3}$ sensors have been developed for incorporation into personal $\mathrm{O}_{3}$ samplers. For example, conductivity sensors based on a heated metal oxide semiconductor (HMOS), including $\mathrm{ZnO}, \mathrm{WO}_{3}, \mathrm{SnO}_{2}, \mathrm{In}_{2} \mathrm{O}_{3}, \mathrm{NiO}$, and $\mathrm{CuO}$ [10-16], have been used to detect $\mathrm{O}_{3}$. The majority of these sensors showed high stability of the baseline and fast response and recovery time with total reversibility. However, $\mathrm{O}_{3}$ sensors based on HMOS suffer from a lack of selectivity in the presence of other gaseous pollutants such as $\mathrm{NO}_{2}[17,18]$.

Electrochemical sensors have also been employed for monitoring air quality in occupational and environmental health applications [19]. They are characterized by their low cost, light weight, and high $\mathrm{O}_{3}$ sensitivity in the range of $5 \mathrm{ppb}$ to $10 \mathrm{ppm}$. However, changes in relative humidity (RH) can generate a significant variation in the signal of the sensor [20]. Besides this, cross-sensitivity with $\mathrm{NO}_{2}$ remains a major problem to eliminate in the case of electrochemical $\mathrm{O}_{3}$ sensors [21].

Gravimetric sensors based on a quartz crystal microbalance (QCM) coating with 1,4-polybutadiene have shown good performance for indoor $\mathrm{O}_{3}$ applications [22]. The polybutadiene-QCM exhibits an irreversible reaction with $\mathrm{O}_{3}$ with a detection limit below $10 \mathrm{ppb}$ [23] and insignificant interference from $\mathrm{NO}_{2}$, formaldehyde, $\mathrm{CO}$, and phenol. However, polymer-coated quartz was found to be unstable with time [24].

Several UV-based $\mathrm{O}_{3}$ monitors have been developed, such as the 2B Technology 205 Dual Beam Ozone Monitor [25] and the Thermo Scientific Model 49i [26]. These instruments exhibit high sensitivity, selectivity, and reliability. However, the size, cost, and regular calibration needs prevent their use for real-time measurements when portability of the equipment is required. A highly portable $\mathrm{O}_{3}$ monitor called the Personal Ozone Monitor (POM) was recently developed by 2B Technologies [27]. This device based on UV absorbance exhibits accurate $(\leq 2 \mathrm{ppb}) \mathrm{O}_{3}$ measurements and a detection limit of $4.5 \mathrm{ppb}$. However, the $\mathrm{POM}$ detects $\mathrm{O}_{3}$ concentrations less precisely in the presence of other pollutants absorbing in the UV domain, such as toluene, ethylbenzene, and xylenes, and for that reason it would be interesting to perform ozone measurements in the visible wavelength range [28].

Various chemiluminescent sensors have been developed for measuring $\mathrm{O}_{3}$ concentrations in ambient air. Most of these devices are based on the light-emitting reaction of $\mathrm{O}_{3}$ in the presence of an excess of ethylene or NO gas $[29,30]$. They present a detection limit of $1 \mathrm{ppb}$, but these devices require a continuous flow of gas supply from a pressurized cylinder, which limits the portability of these instruments. On the other hand, a continuous monitoring system for $\mathrm{O}_{3}$ based on chemiluminescent dye solution has been used. It utilizes ethanol solutions of rhodamine $B$ and gallic acid bubbled with ozonized air. Rhodamine $\mathrm{B}$ shows a high specificity for $\mathrm{O}_{3}$ and a detection limit in the ppm range. However, the high level of noise resulting from the bubble systems is a drawback to using this method for personal monitoring [31].

Besides these, simple and compact $\mathrm{O}_{3}$ sensor devices have been developed based on dye fading colorimetry [32]. These sensors use materials that fade upon reaction with $\mathrm{O}_{3}$ and whose concentration can be quantified by absorbance or reflectance spectroscopy, such as curcumin and indigo carmine [33-35]. An accumulative and passive $\mathrm{O}_{3}$ sensor was proposed by Yasuko Yamada [36] based on porous glass impregnated with indigo carmine. The detection limit of this sensor chip is $3 \mathrm{ppb}$ for a $1 \mathrm{~h}$ exposure, but cross-sensitivity towards $10 \mathrm{ppb}$ of $\mathrm{NO}_{2}$ was observed.

Our aim is to develop an affordable, simple, and portable sensor for $\mathrm{O}_{3}$ monitoring in workplaces, characterized by high sensitivity and selectivity in the presence of other gaseous pollutants. For that purpose, we chose methylene blue (MB), a blue cationic dye that belongs to the phenothiazine family. In previous studies, $\mathrm{MB}$ was used to monitor humidity [37-39]. The degradation of $\mathrm{MB}$ in aqueous solution by $\mathrm{O}_{3}$ was studied by Zhang et al. [40] and by $\mathrm{Al}$ Jibouri et al. [41]. In addition, MB dye immobilized on Nafion ${ }^{\circledR}$ film was used for the detection of hydroxyl radicals in the atmosphere [42] but not applied to $\mathrm{O}_{3}$ monitoring. In this work, a real-time $\mathrm{O}_{3}$ sensor is elaborated by using visible spectroscopy as a measurement method and MB adsorbed on mesoporous silica thin film as the sensing material (Figure 1). A test bench was developed and implemented to produce controlled atmospheres for sensor evaluation. The sensor stability, sensitivity, and selectivity to $\mathrm{O}_{3}$ were investigated. Finally, 
a model and its derivative as a function of time were evaluated to convert in real time the sensor response to a concentration.

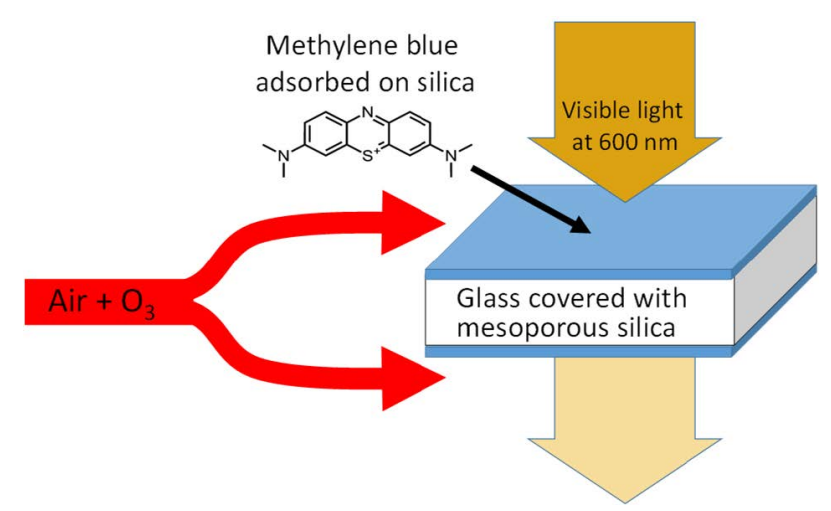

Figure 1. Principle of the sensor. A glass slide is covered on both sides with a mesoporous silica thin film on which methylene blue is adsorbed. Visible light at $600 \mathrm{~nm}$ is absorbed by this colored material. Exposure to $\mathrm{O}_{3}$ in the atmosphere leads to an immediate degradation of the dye. The kinetic of absorbance decrease is immediately translated to a concentration.

\section{Materials and Methods}

\subsection{Chemicals and Reagents}

All chemicals were used without further purification: tetraethoxysilane (TEOS, 98\%, Alfa Aesar, Thermo Fisher, kandel, Germany), cetyltrimethylammonium bromide (CTAB, 99\%, Acros, Thermo Fisher Scientific, Geel, Belgium), absolute ethanol $\left(\mathrm{C}_{2} \mathrm{H}_{5} \mathrm{OH}, 99.8 \%\right.$, Sigma-Aldrich, Merck, St. Quentin Fallavier, France), and hydrochloric acid ( $\mathrm{HCl}, 36 \%$, Prolabo, VWR, Paris, France) were used for the preparation of mesoporous silica films on glass microscope slides (Rogo Sampaic) previously washed with sodium hydroxide ( $\mathrm{NaOH}, 1 \mathrm{M}$, Alfa Aesar, Thermo Fisher, kandel, Germany). Methylene blue ( $>82 \%$, Fluka, Fisher Scientific, Illkirch, France) was used as the $\mathrm{O}_{3}$ sensing material. All solutions were prepared with high-purity water $(18 \mathrm{M} \Omega . \mathrm{cm})$ from a Millipore Milli- ${ }^{\circledR}{ }^{\circledR}$ water purification system (Millipore SAS, Molsheim, France).

\subsection{Sensor Chip Preparation}

Mesoporous silica was prepared with CTAB as the surfactant template and according to the procedure previously reported by Etienne et al. [43]. The initial solution was prepared as follows: A quantity of $0.51 \mathrm{~g}$ of CTAB was dissolved in $0.9 \mathrm{~g}$ of water and $11.66 \mathrm{~g}$ of ethanol with stirring for $30 \mathrm{~min}$ at room temperature. Then, $2.23 \mathrm{~g}$ of TEOS was slowly added into that solution. After that, $0.04 \mathrm{ml}$ of $\mathrm{HCl}\left(1 \mathrm{~mol} \mathrm{~L}^{-1}\right)$ was directly added to the mixture. The final reactant molar ratios were $1 \mathrm{TEOS} / 20 \mathrm{C}_{2} \mathrm{H}_{5} \mathrm{OH} / 5 \mathrm{H}_{2} \mathrm{O} / 0.004 \mathrm{HCl} / 0.14 \mathrm{CTAB}$. The solution was aged at room temperature in sealed vessels for three days before deposition on glass plates of $1 \mathrm{~mm}$ thickness. Prior to use, substrates were shaped into squares of $8 \mathrm{~mm} \times 9 \mathrm{~mm}$ and washed successively with a $1 \mathrm{~mol} \mathrm{~L}^{-1}$ solution of $\mathrm{NaOH}$ and deionized water. The mesoporous silica film was deposited on glass by dip-coating at a withdrawal speed of $2.5 \mathrm{~mm} \mathrm{~s}^{-1}$ and under $50 \% \mathrm{RH}$. Then, the film was stabilized at $130{ }^{\circ} \mathrm{C}$ for $48 \mathrm{~h}$ and calcined at $450{ }^{\circ} \mathrm{C}$ for $5 \mathrm{~h}$ before use. Figure S1 reports the typical mesostructure that was achieved. In addition, the film thickness determined by profilometry was $181 \pm 11 \mathrm{~nm}(N=8)$ (Table S2). Methylene blue was absorbed on mesoporous silica by immersion for $1 \mathrm{~min}$ into a $3 \mathrm{mmol} \mathrm{L}^{-1}$ solution of $\mathrm{MB}$, followed by rinsing with deionized water. After drying at room temperature, a blue film was obtained. The sensing chips were stored in plastic vessels laminated with aluminum. 


\subsection{Experimental Setup}

The setup used in this work is detailed in Figure 2. It was composed of a polluted air generator connected to the sensor. Gas mixtures containing different $\mathrm{O}_{3}$ concentrations were prepared in a cylindrical glass chamber ( $1.5 \mathrm{~L}$ in volume). $\mathrm{O}_{3}$ was generated by passing a flow of dry air through an $\mathrm{O}_{3}$ generator (Thermo Scientific Model $49 i$ UV Photometric $\mathrm{O}_{3}$ Analyzer); the $\mathrm{O}_{3}$ monitor was also used for the control of $\mathrm{O}_{3}$ concentrations in all experiments. Two mass flow controllers were used to dilute $\mathrm{O}_{3}$ gas in purified air in order to achieve lower $\mathrm{O}_{3}$ concentrations $(10-100 \mathrm{ppb})$ in order to be in the range of the concentrations usually measured in workplaces. Humidification to various degrees was controlled by bubbling an adjustable portion of the dilution air through a water bubbler. A Testo435 portable sensor was placed in the glass chamber to monitor the temperature and the relative humidity. The developed sensor was inserted into a $8 \mathrm{~mm}$ width and $1 \mathrm{~mm}$ thickness slot within a brass measuring cell [44] under different $\mathrm{O}_{3}$ concentrations. A pump was used to ensure continuous flow of $\mathrm{O}_{3}$ between 50 and $400 \mathrm{~mL} \mathrm{~min}^{-1}$ inside the measuring cell. The pump was connected to the sampling cell with a Teflon tube. The measuring cell was exposed continuously to visible light emitted from a DH-mini Ocean Optics source. A portable Ocean Optics Flame mini-spectrometer with optical fiber was employed to measure in situ material absorption at a fixed wavelength during the $\mathrm{O}_{3}$ exposure trials. the absorption signal was recorded using OceanView spectroscopy software. An interference study with $\mathrm{NO}_{2}$ was carried out using the same experimental setup previously described. Known concentrations of $\mathrm{NO}_{2}$ were directly generated from a calibration gas cylinder (GasDetect, $27 \mathrm{ppm}$ ) and delivered to the mixing glass chamber via Teflon tubing. In addition, a calibrated mass flow controller was used to dilute $\mathrm{NO}_{2}$ in purified air.

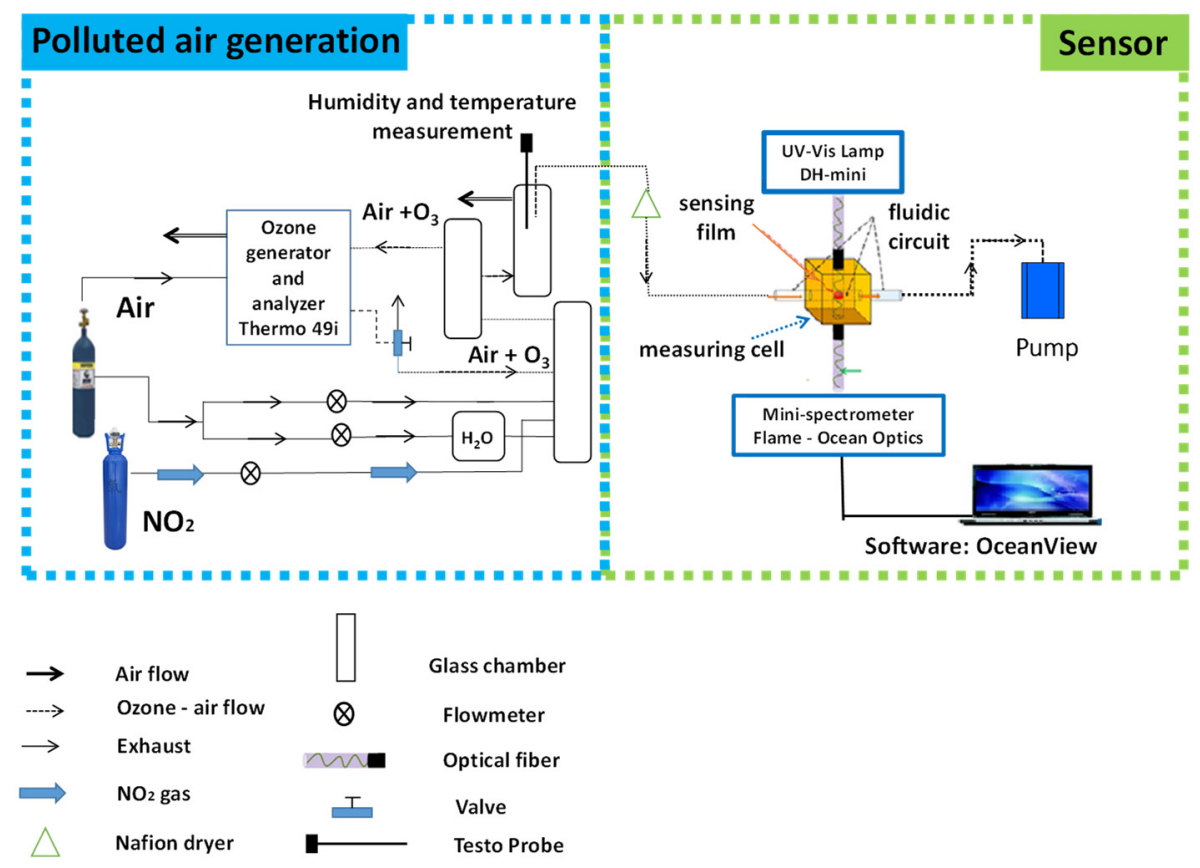

Figure 2. Schematic diagram of the experimental setup.

\subsection{Mathematical Model}

A simple mathematical model was applied to fit with the experimental results by using Equation (1) derived from the pseudo-second-order kinetic equation [45]. This equation takes into account both the rate-limited surface reaction and mass transfer by diffusion in a complex medium:

$$
A_{t}=\left[\frac{\left(A_{t_{0}}-A_{\text {inf }}\right)}{\left(1+k_{0}\left[O_{3}\right] t\left(A_{t_{0}}-A_{\text {inf }}\right)\right)}\right]+A_{\text {inf }}
$$


where $A_{t}$ represents the absorbance at sampling time $t(\mathrm{~min}) ; A_{t_{0}}$ is the initial absorbance at initial time $t_{0}$ (min); $A_{\text {inf }}$ is the absorbance after an infinite $\mathrm{O}_{3}$ sampling time; $\left[\mathrm{O}_{3}\right]$ represents the ozone concentration measured by the $\mathrm{O}_{3}$ analyzer $(\mathrm{ppb})$; and $k_{0}$ is the rate constant of the reaction $\left(\mathrm{ppb}^{-1} \mathrm{~min}^{-1}\right)$.

Moreover, the model previously presented was also applied to predict absorbance variations during $\mathrm{O}_{3}$ exposure at different concentrations. In this case, Equation (2) was used, where $A_{\text {calc }}$ represents the calculated absorbance at sampling time $t$.

$$
A_{\text {calc }}=\left[\frac{\left(A_{t_{0}}-A_{\text {inf }}\right)}{\left(1+k_{0}\left(t-t_{0}\right)\left(A_{t_{0}}-A_{\text {inf }}\right)\left[O_{3}\right]\right)}\right]+A_{\text {inf }}
$$

Additionally, the $\mathrm{O}_{3}$ concentration detected by the developed sensor was calculated by applying Equation (3):

$$
C_{\text {sensor }}=\left[\frac{\left(A_{t_{0}}-A_{t}\right) /\left(A_{t}-A_{\text {inf }}\right)}{k_{0}\left(A_{t_{0}}-A_{\text {inf }}\right)\left(t-t_{0}\right)}\right]
$$

where $C_{\text {sensor }}$ represents the $\mathrm{O}_{3}$ concentration detected by the sensor (ppb).

Finally, we also evaluated the application of the derivative as a function of time (Equation (4)) for concentration determination.

$$
\frac{\partial(A(t))}{\partial t}=\frac{-k_{0}\left(A_{t_{0}}-A_{\text {inf }}\right)^{2} C_{\text {sensor }}}{\left(1+k_{0}\left(A_{t_{0}}-A_{\text {inf }}\right)\left(t-t_{0}\right) C_{\text {sensor }}\right)^{2}}
$$

\section{Results and Discussion}

\subsection{Preliminary Studies}

The visible spectra of methylene blue adsorbed in mesoporous silica show two characteristic absorption peaks of MB at 620 and $665 \mathrm{~nm}$ (Figure 3A), similar to the literature [38]. Preliminary tests were performed to evaluate the sensor response as a function of humidity. When the relative humidity was varied between $2 \%$ and $77 \%$, a significant decrease in absorbance was observed at these two wavelengths (Figure 3A), in agreement with previous reports [46]. On the contrary, the absorbance increased at $560 \mathrm{~nm}$ and at wavelengths higher than $700 \mathrm{~nm}$. Two isosbestic points were found at 600 and $700 \mathrm{~nm}$ for which negligible absorbance variation was observed when the humidity was changed. Figure 3B demonstrates the critical influence of the wavelength on the sensitivity to humidity (see curve (c) for the amplitude of the relative humidity in this experiment). While the absorbance changed dramatically when the measurement was done at $620 \mathrm{~nm}$ (curve (a)), only limited variations in the absorbance were observed at $600 \mathrm{~nm}$ (curve (b)). So, it is possible, by working at $600 \mathrm{~nm}$, to follow the absorbance of methylene blue in the presence of variable relative humidity.

However, humidity also affects the reaction rate of ozone with methylene blue. In another preliminary experiment done at $620 \mathrm{~nm}$ and at $50 \mathrm{~mL} \mathrm{~min}^{-1}$, the sensor was exposed to $108 \mathrm{ppb}$ of $\mathrm{O}_{3}$ in the presence of $1 \%$ (Figure $3 \mathrm{C}$, curve (a)) or $40 \%$ relative humidity (Figure $3 \mathrm{C}$, curve (b)) for almost three hours. The sensor detected $\mathrm{O}_{3}$ in both conditions, but the absorbance decreased more rapidly in dry air than in humid air. We can model the sensor response with Equation (1), and the rate constant of $\mathrm{MB}$ discoloration $\left(\mathrm{k}_{0}\right)$ allows a quantitative assessment of its sensitivity. In a humid atmosphere, the rate constant is $5.61 \times 10^{-5} \mathrm{ppb}^{-1} \mathrm{~min}^{-1}$, while it is almost 2 times higher in dry air at $1.08 \times 10^{-4} \mathrm{ppb}^{-1} \mathrm{~min}^{-1}$ (note that discoloration was homogenous over the all absorbance spectra of $\mathrm{MB}$, so the conclusion of this set of experiments does not depend on the wavelength of measurement). The sensitivity of the sensor was achieved thanks to the reaction between MB adsorbed on porous silica and reactive oxygen species produced from $\mathrm{O}_{3}$ molecules diffusing inside the mesopores of the thin film. The mechanism involves the production of hydroxyl radicals [47]. Tertiary amines are converted to primary amines, and the central ring of the native molecule opens [48]. These reactions 
are probably responsible for the irreversible discoloration. At $40 \%$ relative humidity, the mesopores are partially filled with water [49] which slows down the transfer of the reactive species and modifies the conditions of these reactions. Two strategies can be considered at this step of the sensor development. First, absorbance and air humidity can be monitored simultaneously in order to adjust in real time the sensitivity of the sensor given by $\mathrm{k}_{0}$ during the measurement, so as to determine the $\mathrm{O}_{3}$ concentrations. The second strategy that we applied in this work is to significantly decrease the relative humidity in the air before analysis. This can be achieved by using an efficient gas dryer between the sampling source and the detection cell (see the Supplementary Information associated with Figure S2). Air containing $50 \%$ to $75 \%$ RH (Figure S2, curve (a)) was thereby dried to a level of humidity close to $5 \%(5.5 \pm 1.6)$ in a single pass (Figure S2, curve (b)).
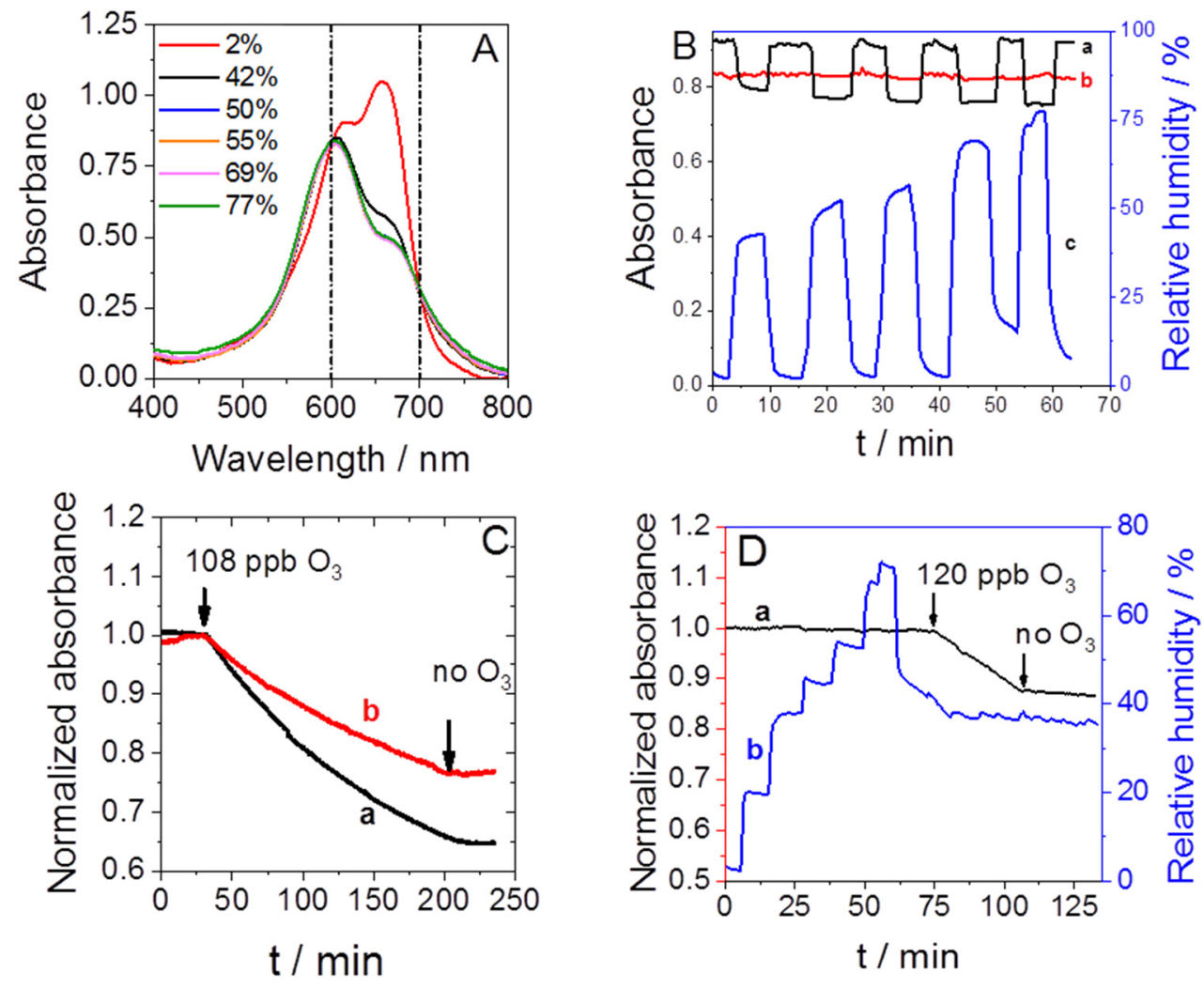

Figure 3. (A) Absorbance of methylene blue in the mesoporous silica in the presence of $2 \%, 42 \%, 50 \%$, $55 \%, 69 \%$, and $77 \%$ relative humidity in air. (B) Absorbance of methylene blue in the mesoporous silica measured as a function of time at $620 \mathrm{~nm}$ (a, black) and $600 \mathrm{~nm}$ (b, red) while the relative humidity varied from $2 \%$ to $77 \%$ (c, blue). (C) Variation of the normalized absorbance in the presence of $108 \mathrm{ppb}$ $\mathrm{O}_{3}$ as a function of time in air with $1 \%$ (a) or $40 \% \mathrm{RH}$ (b). (D) Sensor response as a function of time, relative humidity, and $\mathrm{O}_{3}$ concentration in air (a), and the amplitude of the relative humidity variation as a function of time during the experiment (b).

We applied this air drier in the following $\mathrm{O}_{3}$ exposure trials using a sampling rate of $350 \mathrm{~mL} \mathrm{~min}^{-1}$, and furthermore, all measurements were done at the wavelength of $600 \mathrm{~nm}$, which is not sensitive to minor variations in relative humidity. Figure 3D reports one illustrative experiment, in which the sensor was exposed to various relative humidity levels between $2 \%$ and $72 \%$ before exposure for a duration of $30 \mathrm{~min}$ to $120 \mathrm{ppb}$ of $\mathrm{O}_{3}$ at about $36 \%$ relative humidity. The normalized absorbance was stable as a function of time when the humidity was changed dramatically and decreased only when ozone was present in the analyzed air (first arrow at $74 \mathrm{~min}$ ); it stopped decreasing when $\mathrm{O}_{3}$ was not present (second arrow at $106 \mathrm{~min}$ ). 
The response to $\mathrm{O}_{3}$ was reproducible and stable with time, as illustrated in Figure 4 which reports three measurements made in the presence of $120 \mathrm{ppb}$ ozone and $36 \%$ relative humidity for three hours with sensors prepared from the same batch and analyzed at Days 1, 2, and 50. All measurements show good correlation with the model curve calculated using Equation (2) considering $\mathrm{k}_{0}=8.1 \times 10^{-5} \mathrm{ppb}^{-1} \mathrm{~min}^{-1}$.

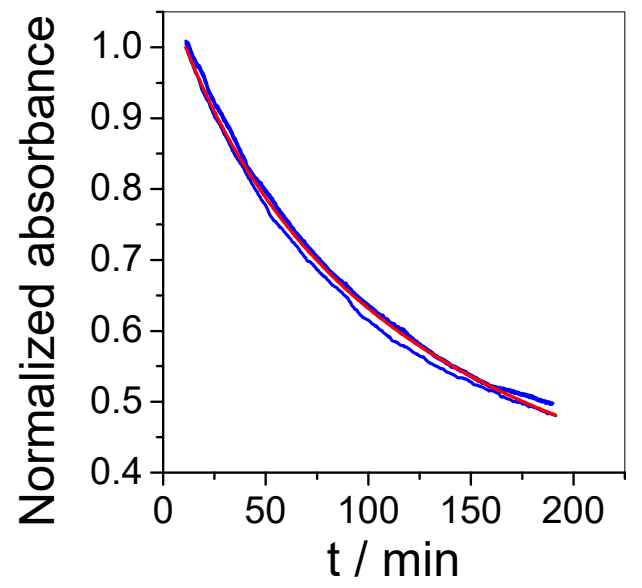

Figure 4. Experimental (blue) and model (red) curves of the normalized absorbance as a function of time in the presence of $120 \mathrm{ppb}$ for three sensors analyzed at Day 1, Day 2, and Day 50 $\left(\mathrm{k}_{0}=8.1 \times 10^{-5} \mathrm{ppb}^{-1} \mathrm{~min}^{-1}\right.$ and $\left.\mathrm{A}_{\mathrm{inf}}=0.137 \pm 0.003\right)$.

\subsection{Sensor Sensitivity and Selectivity}

The performance of the sensor was then evaluated in the presence of $\mathrm{O}_{3}$ concentrations ranging from 10 to $500 \mathrm{ppb}$. Figure S3 reports the gradual discoloration of the sensor chip composed of MB adsorbed on a mesoporous silica thin film when it was exposed to $\mathrm{O}_{3}$. Only a decrease of absorbance was observed, and no other absorption peak appeared in the visible wavelength window during $\mathrm{O}_{3}$ exposure. Figure 5A reports the evolution of the normalized absorbance as a function of time while the $\mathrm{O}_{3}$ concentration was varied stepwise from 10 to $500 \mathrm{ppb}$ in the presence of $36 \%$ relative humidity.
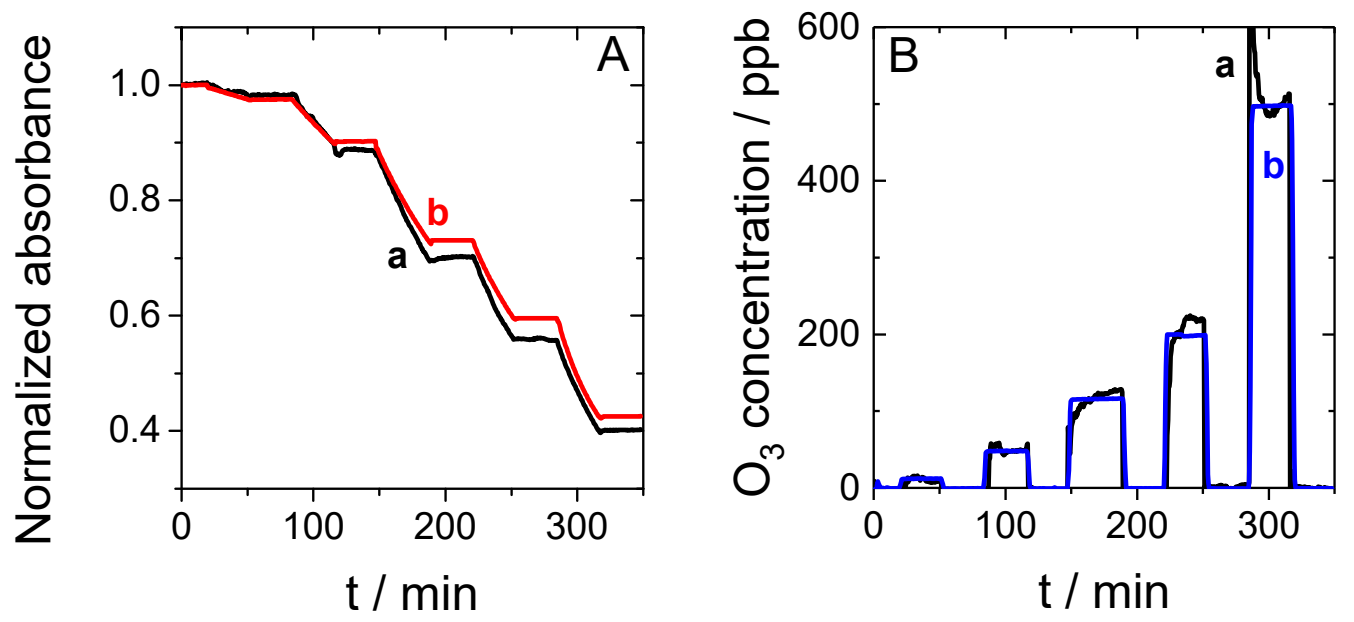

Figure 5. (A) Experimental (a, black) and model (b, red) curves showing the normalized absorbance as a function of time in the presence of increasing concentrations of $\mathrm{O}_{3}$ from 12 to $500 \mathrm{ppb}$. (B) $\mathrm{O}_{3}$ concentration measured as a function of time with the $\mathrm{O}_{3}$ sensor (a, black) and controlled values given by a benchtop $\mathrm{O}_{3}$ analyzer (b, blue).

Each exposure lasted $30 \mathrm{~min}$ and was followed by $30 \mathrm{~min}$ without $\mathrm{O}_{3}$. The absorbance decreased in the presence of $\mathrm{O}_{3}$ and did not vary in the absence of $\mathrm{O}_{3}$. Curve (a) presents the experimental data 
and curve (b) shows the model derived from Equation (2). Moreover, we evaluated the possibility to determine the concentration of $\mathrm{O}_{3}$ directly from the sensor response using Equation (3). Figure 5B reports the comparison of the sensor response as a function of time with the controlled concentration given by the $\mathrm{O}_{3}$ analyzer (see Figure 2 to visualize the position of this analyzer versus the sensor in the setup). As can be observed, a good correlation was found between the generated $\mathrm{O}_{3}$ concentration (curve (b)) and the sensor response (curve (a)) up to $10 \mathrm{ppb}$, i.e., far below the OEL for $\mathrm{O}_{3}$, which is $100 \mathrm{ppb}$ for $8 \mathrm{~h}$ monitoring and $200 \mathrm{ppb}$ for $15 \mathrm{~min}$ monitoring. In conclusion, the sensor provides sufficient sensitivity and measurement range (tested here up to $500 \mathrm{ppb}$ ) for $\mathrm{O}_{3}$ monitoring in working environments. Moreover, it provides a rapid warning for the exposed worker and temporally resolved data on $\mathrm{O}_{3}$ concentrations.

In addition to sensor sensitivity, it is important to evaluate cross-sensitivity resulting from gaseous pollutant compounds. The measurement of $\mathrm{O}_{3}$ in occupational environments is mainly affected by other oxidizing gases such as $\mathrm{NO}_{2}$ and sulfur dioxide $\left(\mathrm{SO}_{2}\right)$ [50,51]. In the following interference testing, the cross-sensitivity versus $\mathrm{NO}_{2}$ was evaluated. Experiments were carried out by exposing the sensors to $510 \mathrm{ppb}$ of $\mathrm{NO}_{2}$. The selected $\mathrm{NO}_{2}$ concentration is based on the OEL fixed in the recommendation for $\mathrm{NO}_{2}$ by the Scientific Committee on Occupational Exposure Limits (SCOEL) [52].

Figure $6 \mathrm{~A}$ shows the normalized absorbance variation at $600 \mathrm{~nm}$ as a function of time when the sensor was exposed to $134 \mathrm{ppb}$ of $\mathrm{O}_{3}$ followed by exposure to $510 \mathrm{ppb}$ of $\mathrm{NO}_{2}$ and, finally, to a mixture of $134 \mathrm{ppb} \mathrm{O}_{3}$ and $510 \mathrm{ppb} \mathrm{NO}$. The sensor showed a significant response during each exposure to $\mathrm{O}_{3}$ (1st at $30 \mathrm{~min}, 2 \mathrm{nd}$ at $190 \mathrm{~min}$, and 3rd at $250 \mathrm{~min}$ ). Oppositely, no response was observed when the sensor was exposed to $510 \mathrm{ppb}$ from 100 to $160 \mathrm{~min}$ and after $294 \mathrm{~min}$. Thus, $\mathrm{NO}_{2}$ did not interfere in the detection of $\mathrm{O}_{3}$.
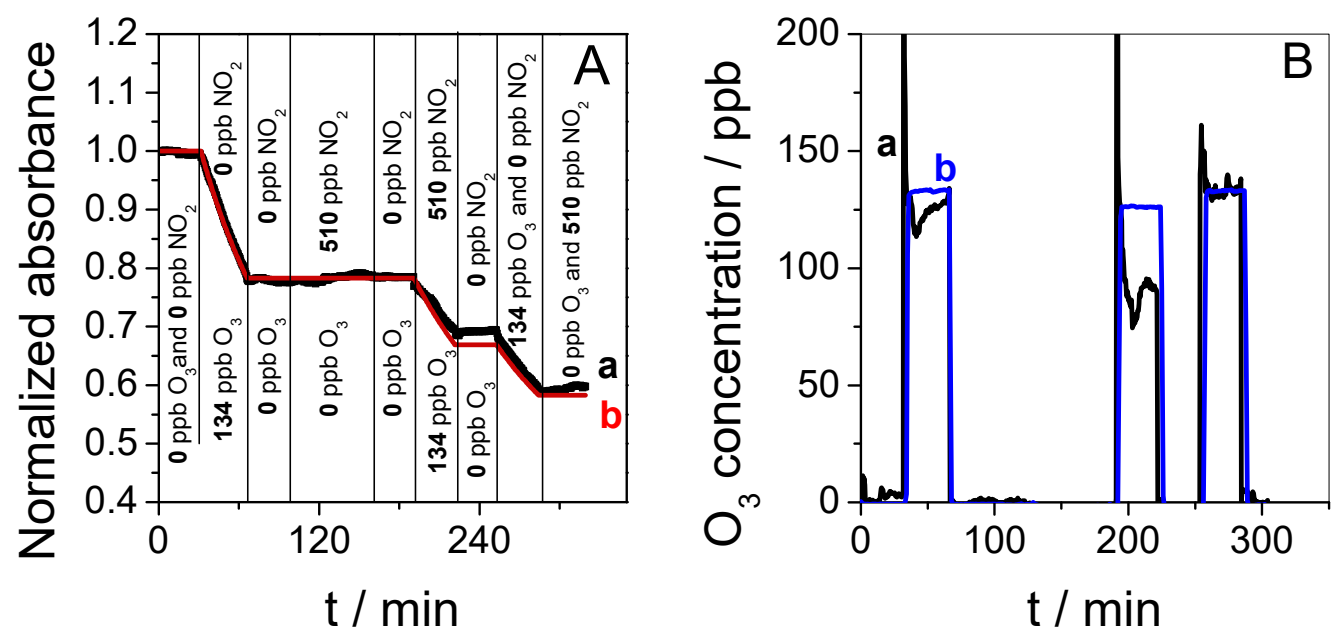

Figure 6. (A) Experimental (a, black) and model (b, red) curves showing the normalized absorbance as a function of time in the presence of 0 or $134 \mathrm{ppb}$ of $\mathrm{O}_{3}$ and 0 or $510 \mathrm{ppb} \mathrm{NO}_{2}$. (B) $\mathrm{O}_{3}$ concentration measured as function of time with the $\mathrm{O}_{3}$ sensor (a, black) and controlled values given by a benchtop $\mathrm{O}_{3}$ analyzer (b, blue). The test was performed at $24^{\circ} \mathrm{C}$, with air at $50 \% \mathrm{RH}$ passing through the Nafion ${ }^{\circledR}$ tube at a flow rate of $350 \mathrm{~mL} \mathrm{~min}^{-1}$ and using a sampling time of $30 \mathrm{~min}$.

Figure $6 \mathrm{~B}$ reports the $\mathrm{O}_{3}$ concentration determined with Equation (3) during this complex scenario. The ozone concentration measured by the sensor (curve (a)) and the concentration measured by an $\mathrm{O}_{3}$ analyzer (curve (b)) fitted well when $\mathrm{O}_{3}$ was introduced alone in air. However, when $134 \mathrm{ppb}$ $\mathrm{O}_{3}$ was generated in the presence of $510 \mathrm{ppb} \mathrm{NO}_{2}$, the concentration determined at the sensor was close to $90 \mathrm{ppb}$. Interestingly, the concentration determined with the $\mathrm{O}_{3}$ analyzer was also lower than expected-only $125 \mathrm{ppb}$ was measured. In the gas mixture, the $\mathrm{NO}_{2}$ concentration was 5 times larger 
than that of $\mathrm{O}_{3}$. In these conditions, the reaction between the two molecules induces the formation of $\mathrm{NO}_{3}$ and $\mathrm{N}_{2} \mathrm{O}_{5}$ according to Reaction 1 followed by Reaction 2 [53,54].

$$
\begin{aligned}
& \mathrm{NO}_{2}+\mathrm{O}_{3} \rightarrow \mathrm{NO}_{3}+\mathrm{O}_{2} \\
& \mathrm{NO}_{3}+\mathrm{NO}_{2} \rightleftharpoons \mathrm{N}_{2} \mathrm{O}_{5} \\
& 2 \mathrm{NO}_{2}+\mathrm{H}_{2} \mathrm{O} \rightarrow \mathrm{HNO}_{3}+\mathrm{HNO}_{2}
\end{aligned}
$$

Furthermore, the presence of $\mathrm{HNO}_{3}$ resulting from Reaction 3 between $\mathrm{NO}_{2}$ and humidity is also possible. As a result, the initial $\mathrm{O}_{3}$ concentration generated is partly consumed by the formation of other gaseous species. In the experimental setup reported in Figure 2, the $\mathrm{O}_{3}$ analyzer was positioned in the fluidic system far before the sensor, and it is very possible that the real $\mathrm{O}_{3}$ concentration measured by the sensor is lower than that measured by the $\mathrm{O}_{3}$ analyzer because of the additional time needed for gas transfer leading to higher reaction progress before detection. To conclude, $\mathrm{NO}_{2}$ was not detected by the sensor based on methylene blue in mesoporous silica thin film, and the accuracy of the determination of $\mathrm{O}_{3}$ in the presence of $\mathrm{NO}_{2}$ depends essentially on the fluidic length between the sampling source and the detector, which must be as short as possible.

\subsection{Application of the Sensor in a Complex Scenario}

To finalize this study, we evaluated the sensor in a more complex scenario during which both relative humidity (from $35 \%$ to $52 \%$ and $62 \%$ ) and $\mathrm{O}_{3}$ concentration (from 10 to $200 \mathrm{ppb}$ ) were varied every five- to ten-minute period for almost two hours (Figure 7). The normalized absorbance profile of this experiment and the model absorbance curve, calculated according to Equation (2), can be found in Figure S4. The sensor response was first determined by applying Equation (3) to the experimental absorbance data and then compared to the concentration given by the $\mathrm{O}_{3}$ analyzer used here as a control. The low concentrations of $\mathrm{O}_{3}$, below $60 \mathrm{ppb}$, were well determined, but a significant difference was observed between the expected concentration (control) and the sensor response at this relatively short time scale, resulting in an error of about $30 \%$. The reason for this could be that the time requested to reach a constant value of $\mathrm{O}_{3}$ concentration in the measuring setup is not negligible when a short exposure time is used. Oppositely, concentration steps of $30 \mathrm{~min}$ were accurately determined (Figures 5 and 6). Moreover, Equation (3), used to convert absorbance to concentration, is potentially sensitive to a cumulative shift in the absorbance value, leading then to errors in the determination of $\mathrm{O}_{3}$ concentrations. These limits were overpassed by treating data with the derivative as a function of time, given in Equation (4). This method allows us to achieve rapid determination of the concentration that was introduced in air (see the blue triangle curve in Figure 7) and to prevent cumulative errors. Finally, this experiment confirmed that the water content in air from $35 \%$ to $62 \%$ relative humidity does not produce any interference in the $\mathrm{O}_{3}$ determination. We tested the derivative of the absorbance as a function of time for the treatment of data collected with different concentrations of $\mathrm{O}_{3}$ (Figure S5) and in the presence of $\mathrm{NO}_{2}$ (Figure S6). Despite the large noise, essentially due to the data collection parameters that were not optimal, it is clear that the method allows rapid determination of concentrations in these different conditions. 


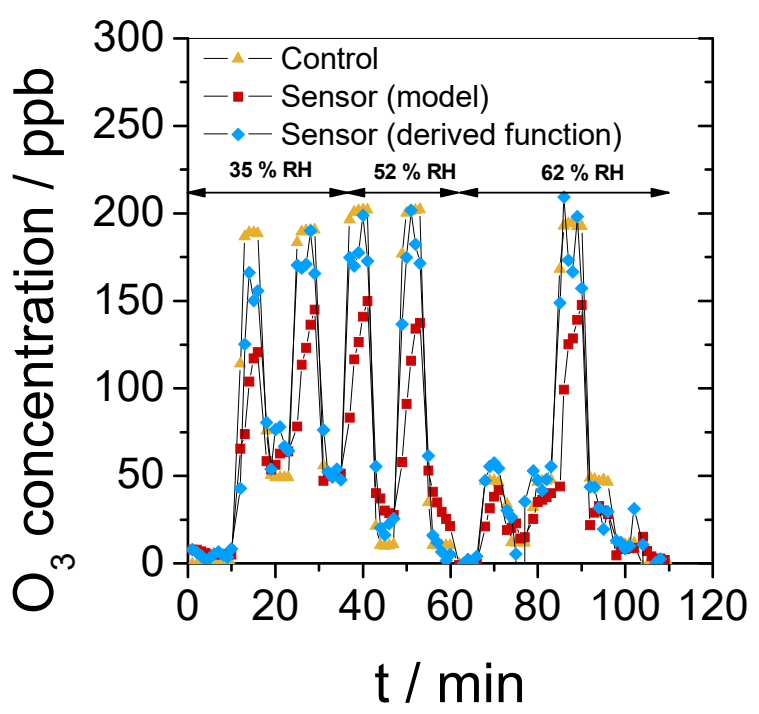

Figure 7. $\mathrm{O}_{3}$ concentration measured as function of time with a benchtop $\mathrm{O}_{3}$ analyzer for control (triangle) and the sensor using Equation (3) (square) or the derivative as a function of time (Equation (4), lozenge). In this scenario, the $\mathrm{O}_{3}$ concentration was varied every five to ten minutes from 0 to 10 or 50 or $200 \mathrm{ppb}$, and the relative humidity in air was changed from $35 \%$ to $52 \%$ and, finally, $62 \%$.

\section{Conclusions}

In this study, a real-time optical $\mathrm{O}_{3}$ sensor based on methylene blue adsorbed in a mesoporous silica thin film was successfully developed. The device includes a Nafion ${ }^{\circledR}$ dryer to eliminate the interference of water. At $600 \mathrm{~nm}$, the sensor exhibited interesting performance: it showed significant sensitivity at low $\mathrm{O}_{3}$ concentrations up to $10 \mathrm{ppb}$, good reproducibility and stability up to 50 days in the absence of $\mathrm{O}_{3}$, and no direct interference by $\mathrm{NO}_{2}$. The derivative of the absorbance as a function of time was proposed to reach a fast and accurate response to changes in $\mathrm{O}_{3}$ concentration. The next step in this research is the miniaturization of the sensor for analytical performance evaluation in workplaces and real-time monitoring of $\mathrm{O}_{3}$ exposure that will contribute to a safer working environment. The sensor will operate at a wavelength close to $600 \mathrm{~nm}$ and will integrate air sampling in a portable device.

Supplementary Materials: The following are available online at http://www.mdpi.com/1424-8220/19/16/3508/s1.

Author Contributions: Conceptualization, C.G., M.H., E.L., B.C., M.G. and M.E.; Data curation, C.G. and M.H.; Formal analysis, M.H.; Investigation, C.G., B.C. and M.G.; Methodology, M.H.; Project administration, E.L.; Supervision, M.H., M.G. and M.E.; Validation, M.H., E.L., M.G. and M.E.; Visualization, C.G., M.G. and M.E.; Writing —original draft, C.G.; Writing—review \& editing, M.G. and M.E.

Funding: This research was funded by the National Institute for Research and Safety INRS—France.

Acknowledgments: The authors wish to thank Jaafar Ghanbajaa (Institut Jean Lamour, Nancy, France) for the TEM analysis.

Conflicts of Interest: The authors declare no conflict of interest.

\section{References}

1. Singer, B.C.; Coleman, B.K.; Destaillats, H.; Hodgson, A.T.; Lunden, M.M.; Weschler, C.J.; Nazaroff, W.W. Indoor secondary pollutants from cleaning product and air freshener use in the presence of ozone. Atmos. Environ. 2006, 40, 6696-6710. [CrossRef]

2. Wang, H.; He, C.; Morawska, L.; McGarry, P.; Johnson, G. Ozone-initiated particle formation, particle aging, and precursors in a laser printer. Environ. Sci. Technol. 2012, 46, 704-712. [CrossRef] [PubMed]

3. Inrs Fiche Toxicologique ${ }^{\circ} 43$ : Ozone. Available online: http://www.inrs.fr/publications/bdd/fichetox/fiche. html?refINRS=FICHETOX_43 (accessed on 9 August 2019). 
4. Kampa, M.; Castanas, E. Human health effects of air pollution. Environ. Pollut. 2008, 151, 362-367. [CrossRef] [PubMed]

5. Demirel, G.; Özden, Ö.; Döğeroğlu, T.; Gaga, E.O. Personal exposure of primary school children to BTEX, NO2and ozone in Eskişehir, Turkey: Relationship with indoor/outdoor concentrations and risk assessment. Sci. Total Environ. 2014, 473-474, 537-548. [CrossRef] [PubMed]

6. Liard, R.; Zureik, M.; Le Moullec, Y.; Soussan, D.; Glorian, M.; Grimfeld, A.; Neukirch, F. Use of personal passive samplers for measurement of $\mathrm{NO}_{2}, \mathrm{NO}$, and $\mathrm{O}_{3}$ levels in panel studies. Environ. Res. 1999, 81, 339-348. [CrossRef] [PubMed]

7. Bernard, N.L.; Gerber, M.J.; Astre, C.M.; Saintot, M.J. Ozone measurement with passive samplers: Validation and use for ozone pollution assessment in Montpellier, France. Environ. Sci. Technol. 1999, 33, 217-222. [CrossRef]

8. Surgi, M.R.; Hodgeson, J.A. 10,10'-Dimethyl-9,9'-biacridylidene Impregnated Film Badge Dosimeters for Passive Ozone Sampling. Anal. Chem. 1985, 57, 1737-1740. [CrossRef]

9. Geyh, A.S.; Wolfson, J.M.; Koutrakis, P.; Mulik, J.D.; Avol, E.L. Development and evaluation of a small active ozone sampler. Environ. Sci. Technol. 1997, 31, 2326-2330. [CrossRef]

10. Acuautla, M.; Bernardini, S.; Gallais, L.; Fiorido, T.; Patout, L.; Bendahan, M. Ozone flexible sensors fabricated by photolithography and laser ablation processes based on $\mathrm{ZnO}$ nanoparticles. Sens. Actuators B Chem. 2014, 203, 602-611. [CrossRef]

11. Vallejos, S.; Khatko, V.; Aguir, K.; Ngo, K.A.; Calderer, J.; Gràcia, I.; Cané, C.; Llobet, E.; Correig, X. Ozone monitoring by micro-machined sensors with $\mathrm{WO}_{3}$ sensing films. Sens. Actuators B Chem. 2007, 126, 573-578. [CrossRef]

12. Korotcenkov, G.; Blinov, I.; Brinzari, V.; Stetter, J.R. Effect of air humidity on gas response of $\mathrm{SnO}_{2}$ thin film ozone sensors. Sens. Actuators B Chem. 2007, 122, 519-526. [CrossRef]

13. Korotcenkov, G.; Cerneavschi, A.; Brinzari, V.; Vasiliev, A.; Ivanov, M.; Cornet, A.; Morante, J.; Cabot, A.; Arbiol, J. $\mathrm{In}_{2} \mathrm{O}_{3}$ films deposited by spray pyrolysis as a material for ozone gas sensors. Sens. Actuators B Chem. 2004, 99, 297-303. [CrossRef]

14. Kang, G.; Zhu, Z.; Tang, B.H.; Wu, C.H.; Wu, R.J. Rapid detection of ozone in the parts per billion range using a novel Ni-Al layered double hydroxide. Sens. Actuators B Chem. 2017, 241, 1203-1209. [CrossRef]

15. Bejaoui, A.; Guerin, J.; Zapien, J.A.; Aguir, K. Theoretical and experimental study of the response of $\mathrm{CuO}$ gas sensor under ozone. Sens. Actuators B Chem. 2014, 190, 8-15. [CrossRef]

16. Thirumalairajan, S.; Mastelaro, V.R.; Escanhoela, C.A. In-Depth Understanding of the Relation between CuAlO 2 Particle Size and Morphology for Ozone Gas Sensor Detection at a Nanoscale Level. ACS Appl. Mater. Interfaces 2014, 6, 21739-21749. [CrossRef]

17. Sizun, T.; Bouvet, M.; Chen, Y.; Suisse, J.; Barochi, G.; Rossignol, J. Differential study of substituted and unsubstituted cobalt phthalocyanines for gas sensor applications. Sens. Actuators B. Chem. 2011, 159, 163-170. [CrossRef]

18. Brunet, J.; Pauly, A.; Mazet, L.; Germain, J.P.; Bouvet, M.; Malezieux, B. Improvement in real time detection and selectivity of phthalocyanine gas sensors dedicated to oxidizing pollutants evaluation. Thin Solid Films 2005, 490, 28-35. [CrossRef]

19. Ashley, K. Developments in electrochemical sensors for occupational and environmental health applications. J. Hazard. Mater. 2003, 102, 1-12. [CrossRef]

20. Pang, X.; Shaw, M.D.; Lewis, A.C.; Carpenter, L.J.; Batchellier, T. Electrochemical ozone sensors: A miniaturised alternative for ozone measurements in laboratory experiments and air-quality monitoring. Sens. Actuators B Chem. 2017, 240, 829-837. [CrossRef]

21. Knake, R.; Hauser, P.C. Sensitive electrochemical detection of ozone. Anal. Chim. Acta 2002, 459, $199-207$. [CrossRef]

22. Muller, J.B.A.; Smith, C.E.; Newton, I.; Percival, C.J. Evaluation of coated QCM for the detection of atmospheric ozone. Analyst 2011, 136, 2963-2968. [CrossRef]

23. Black, D.R.; Harley, R.A.; Hering, S.V.; Stolzenburg, M.R. A new, portable, real-time ozone monitor. Environ. Sci. Technol. 2000, 34, 3031-3040. [CrossRef]

24. Fog, H.M.; Rietz, B. Piezoelectric crystal detector for the monitoring of Ozone in working environments.pdf. Anal. Chem. 1985, 57, 2638-2643. [CrossRef] 
25. 2BTechnologies Ozone Monitor. Available online: https://twobtech.com/docs/manuals/model_202_revH.pdf (accessed on 9 August 2019).

26. Fisher, T. UV Photometric O3 Analyzer Model 49i. Available online: https://www.thermofisher.com/order/ catalog/product/49i (accessed on 9 August 2019).

27. Andersen, P.C.; Williford, C.J.; Birks, J.W. Miniature personal ozone monitor based on UV absorbance. Anal. Chem. 2010, 82, 7924-7928. [CrossRef]

28. Sagona, J.A.; Weisel, C.P.; Meng, Q. Accuracy and practicality of a portable ozone monitor for personal exposure estimates. Atmos. Environ. 2018, 175, 120-126. [CrossRef]

29. Grosjean, D.; Harrison, J. Response of Chemiluminescence NO, Analyzers and Ultraviolet Ozone Analyzers to Organic Air Pollutants. Environ. Sci. Technol. 1985, 19, 862-865. [CrossRef]

30. Warren, G.J.; Babcock, G. Portable ethylene chemiluminescence ozone monitor. Rev. Sci. Instrum. 1970, 41, 280-282. [CrossRef]

31. Ray, J.D.; Stedman, D.H.; Wendel, G.J. Fast Chemiluminescent Method for Measurement of Ambient Ozone. Anal. Chem. 1986, 58, 598-600. [CrossRef]

32. Ando, M. Recent advances in optochemical sensors for the detection of $\mathrm{H}_{2}, \mathrm{O}_{2}, \mathrm{O}_{3}, \mathrm{CO}, \mathrm{CO}_{2}$ and $\mathrm{H}_{2} \mathrm{O}$ in air. TrAC Trends Anal. Chem. 2006, 25, 937-948. [CrossRef]

33. Bergshoeff, G.; Lanting, R.W.; Van Ham, J.; Prop, J.M.G.; Reijnders, H.F.R. Spectrophotometric Determination of Ozone in Air with Indigo Disulphonate. Analyst 1984, 109, 1165-1169. [CrossRef]

34. Alexy, M.; Voss, G.; Heinze, J. Optochemical sensor for determining ozone based on novel soluble indigo dyes immobilised in a highly permeable polymeric film. Anal. Bioanal. Chem. 2005, 382, 1628-1641. [CrossRef]

35. Grosjean, D.; Hisham, M.W.M. A passive sampler for atmospheric ozone. J. Air Waste Manag. Assoc. 1992, 42, 169-173. [CrossRef]

36. Maruo, Y.Y. Measurement of ambient ozone using newly developed porous glass sensor. Sens. Actuators $B$ 2007, 126, 485-491. [CrossRef]

37. Zanjanchi, M.A.; Sohrabnezhad, S. Evaluation of methylene blue incorporated in zeolite for construction of an optical humidity sensor. Sens. Actuators B Chem. 2005, 105, 502-507. [CrossRef]

38. Fernández-Ramos, M.D.; Ordóñez, Y.F.; Capitán-Vallvey, L.F.; De Vargas-Sansalvador, I.M.P.; Ballesta-Claver, J. Optical humidity sensor using methylene blue immobilized on a hydrophilic polymer. Sens. Actuators B Chem. 2015, 220, 528-533. [CrossRef]

39. Ishizaki, R.; Katoh, R. Fast-response humidity-sensing films based on methylene blue aggregates formed on nanoporous semiconductor films. Chem. Phys. Lett. 2016, 652, 36-39. [CrossRef]

40. Zhang, J.; Lee, K.H.; Cui, L.; Jeong, T. Degradation of methylene blue in aqueous solution by ozone-based processes. J. Ind. Eng. Chem. 2009, 15, 185-189. [CrossRef]

41. Al jibouri, A.K.H.; Wu, J.; Upreti, S.R. Continuous ozonation of methylene blue in water. J. Water Process Eng. 2015, 8, 142-150. [CrossRef]

42. Iwamori, S.; Nishiyama, N.; Oya, K. A colorimetric indicator for detection of hydroxyl radicals in atmosphere using a methylene blue dye based on nafion film. Polym. Degrad. Stab. 2016, 123, 131-136. [CrossRef]

43. Etienne, M.; Quach, A.; Grosso, D.; Nicole, L.; Sanchez, C.; Walcarius, A. Molecular Transport into Mesostructured Silica Thin Films: Electrochemical Monitoring and Comparison between p 6 m, P6 3/mmc, and Pm 3 n Structures. Chem. Mater. 2007, 19, 844-856. [CrossRef]

44. Hamdi, K.; Hébrant, M.; Martin, P.; Galland, B.; Etienne, M. Mesoporous silica nanoparticle film as sorbent for in situ and real-time monitoring of volatile BTX (benzene, toluene and xylenes). Sens. Actuators B Chem. 2016, 223, 904-913. [CrossRef]

45. Plazinski, W.; Dziuba, J.; Rudzinski, W. Modeling of sorption kinetics: The pseudo-second order equation and the sorbate intraparticle diffusivity. Adsorption 2013, 19, 1055-1064. [CrossRef]

46. Mills, A.; Hawthorne, D.; Burns, L.; Hazafy, D. Novel temperature-activated humidity-sensitive optical sensor. Sens. Actuators B Chem. 2017, 240, 1009-1015. [CrossRef]

47. Staehelln, J.; Hoigne, J. Decomposition of Ozone in Water in the Presence of Organic Solutes Acting as Promoters and Inhibitors of Radical Chain Reactions. Environ. Sci. Technol. 1985, 19, 1206-1213. [CrossRef]

48. Huang, F.; Chen, L.; Wang, H.; Yan, Z. Analysis of the degradation mechanism of methylene blue by atmospheric pressure dielectric barrier discharge plasma. Chem. Eng. J. 2010, 162, 250-256. [CrossRef] 
49. Boissiere, C.; Grosso, D.; Lepoutre, S.; Nicole, L.; Bruneau, A.B.; Sanchez, C. Porosity and mechanical properties of mesoporous thin films assessed by environmental ellipsometric porosimetry. Langmuir 2005, 21, 12362-12371. [CrossRef]

50. Izumi, K.; Utiyama, M.; Maruo, Y.Y. A porous glass-based ozone sensing chip impregnated with potassium iodide and $\alpha$-cyclodextrin. Sens. Actuators B Chem. 2017, 241, 116-122. [CrossRef]

51. Aleixandre, M.; Del Carmen Horrillo, M.; Gerboles, M.; Spinelle, L.; Bonavitacola, F. Comparison of Tin Dioxide Ozone Sensor Operated in On/Off Switching Temperature Cycles and at Constant Temperature. Chem. Eng. Trans. 2016, 54, 49-54.

52. European Commission (EC). Recommendation from the Scientific Committee on Occupational Exposure Limits (SCOEL) for Nitrogen Dioxide. Available online: https:/www.google.com.hk/url?sa=t\&rct=j\&q= \&esrc $=$ \&\&source $=$ web\&cd=4\&ved =2ahUKEwjH8bz2nvfjAhXbxosBHQ2cAzAQFjADegQIAxAC\&url= http $\% 3 \mathrm{~A} \% 2 \mathrm{~F} \% 2 \mathrm{Fec}$.europa.eu $\% 2$ Fsocial\%2FBlobServlet $\% 3$ FdocId $\% 3 \mathrm{D} 12432 \% 26$ langId $\% 3$ Den\&usg= AOvVaw14WVsmj6Vff1fsg_aWeZv2 (accessed on 9 August 2019).

53. Wu, C.H.; Morris, E.D.; Niki, H. The reaction of nitrogen dioxide with ozone. J. Phys. Chem. 1973, 77, 2507-2511. [CrossRef]

54. Wang, H.; Zhuang, Z.; Sun, C.; Zhao, N.; Liu, Y.; Wu, Z. Numerical evaluation of the effectiveness of $\mathrm{NO}_{2}$ and $\mathrm{N}_{2} \mathrm{O}_{5}$ generation during the $\mathrm{NO}$ ozonation process. J. Environ. Sci. 2016, 41, 51-58. [CrossRef]

(C) 2019 by the authors. Licensee MDPI, Basel, Switzerland. This article is an open access article distributed under the terms and conditions of the Creative Commons Attribution (CC BY) license (http://creativecommons.org/licenses/by/4.0/). 